\title{
THE IMPLEMENTATION OF MEDICAL AND SOCIAL REHABILITATION FOR ADDICTS AND NARCOTICS ABUSE
}

\author{
IBNU SAKDAN \\ Mahasiswa \\ Program Magister Ilmu Hukum \\ Fakultas Hukum Universitas Syiah Kuala \\ ibnusakdan@hotmail.com
}

DAHLAN ALI

Dosen Fakultas Hukum Universitas Syiah Kuala

Jalan Putroe Phang, No. 1 Darussalam, Banda Aceh.

MAHFUD

Dosen Fakultas Hukum Universitas Syiah Kuala Jalan Putroe Phang, No. 1 Darussalam, Banda Aceh.

\begin{abstract}
This study examines the reasons for judges not ordering rehabilitation for narcotics abuse offenders, as stipulated in Article 127 paragraph (2) of Law No. 35 of 2009 concerning Narcotics. It also investigates the implementation of medical and social rehabilitation conducted in the jurisdictions of Banda Aceh and Aceh Besar. In handling narcotics abuse cases in Banda Aceh and Jantho from 2015 to 2017, there was only one decision ordering rehabilitation for the offenders, while others were sentenced to prison terms. The judge did not order for rehabilitation, because the expert was not present at the court to explain that the narcotics addicts needed rehabilitation, the offenders denied that they were narcotics addicts, and the public prosecutor had never demanded the defendant to be rehabilitated. In 2015 and 2016, the rehabilitation program was implemented by the National Narcotics Agency (BNN), but it stopped in the following year due to the insufficient budget. The rehabilitation carried out is medical and social rehabilitation, an integrated treatment to cure addicts of narcotics addiction as well as mental and social recovery so that ex-addicts are ready to return to society.
\end{abstract}

Keywords: Narcotics, Rehabilitation, Policy

Abstrak: Artikel ini meneliti mengapa hakim tidak memutuskan rehabilitasi bagi pelaku penyalahgunaan narkotika sebagai mana ketentuan Pasal 127 ayat (2) Undang-undang No. 35 tahun 2009 tentang Narkotika, serta meneliti bagaimana pelaksanaan rehabilitasi medis dan sosial yang dilaksanakan di wilayah hukum Banda Aceh dan Aceh Besar. Dalam penanganan perkara penyalah guna narkotika di Pengadilan Negeri Banda Aceh dan Pegadilan Negeri Jantho dalam tahun 2015 sampai dengan tahun 2017 hanya ada satu putusan yang memerintahkan merehabilitasi pelaku, sedangkan pelaku lain dihukum hukuman penjara. Hakim tidak memutuskan rehabilitasi, karena tidak dihadirkannya ahli ke persidangan untuk menerangkan bahwa pecandu narkotika memerlukan rehabilitasi, dan pelaku tidak mau mengakui sebagai pecandu narkotika, serta penuntut umum juga tidak pernah menuntut terdakwa untuk direhabilitasi. Pada tahun 2015 dan 2016 program rehabilitasi dilaksanakan oleh pihak BNN, namun tahun berikutnya tidak dilaksanakan lagi karena tidak tersedianya anggaran. Rehabilitasi yang 
dilaksanakan adalah rehabilitasi medis dan sosial berupa pengobatan secara terpadu untuk membebaskan pecandu dari ketergantungan narkotika serta pemulihan mental maupun sosial sehingga bekas pecandu siap kembali dalam masyarakat.

\section{Kata Kunci: Narkotika, Rehabilitasi, Kebijakan}

\section{Introduction}

This study examines the reasons for judges not ordering rehabilitation for narcotics abuse offenders. Law No. 35 of 2009, Article 127 paragraph (2), concerning Narcotics, regulates that judges in deciding cases of narcotics abuse offenders must consider those concerned to undergo treatment and or treatment through a rehab program.

One effort to provide narcotics abusers a comprehensive understanding is to conduct a rehab program, as accommodated in the legislation. Rehabilitation for addicts and drug abuse offenders can be done in two ways.

1. Medical Rehabilitation is a process of integrated medical activities to free the addicts of Narcotics dependence. ${ }^{1}$

2. Social Rehabilitation is a process of integrated recovery activities, such as physical, mental, and social recovery, so that former Narcotics addicts can return and function socially in society. ${ }^{2}$

Aswin Pramudita argued that rehabilitation is vital for the victims or offenders of narcotics abuse. The program aims to guide them and it is hoped that it can benefit them for their life following the rehabilitation. ${ }^{3}$ Rehabilitation of the illicit drug trafficking victims is a comprehensive approach. ${ }^{4}$

Rehabilitation, other than regulated in the Narcotics Law, has also been regulated in the provisions of Article 7 of the Joint Regulations of the Indonesian government. The provision stipulates that for the prisoners who are in the category of narcotics addicts and victims of narcotics abuse, and non-dealers or couriers or producers, medical and or social rehabilitation can be conducted in prisons or detention centers and or

\footnotetext{
Pasal 1 angka 16, Undang-undang Nomor 35 tahun 2009 tentang Narkotika. Pasal 1 angka 16, Undang-undang Nomor 35 tahun 2009 tentang Narkotika. Aswin Pramudita, Pertimbangan Hukum Hakim Menjatuhkan Sanksi Pidana Penjara Terhadap Penyalahgunaan Narkotika Tanpa Menerapkan Rehabilitasi Medis (Studi Putusan Nomor: 100/PID.SUS/2015/PN.SKT), Jurnal Verstek, Volume 5 No. 2 Mei-AguMay-August 2017, 343.

$4 \quad$ Hafrida, Kebijakan Hukum Pidana Terhadap Pengguna Narkotika Sebagai Korban bukan Pelaku Tindak Pidana : Studi Lapangan Daerah Jambi, Jurnal Ilmu Hukum, Universitas Padjajaran, vol. 3, Number 1, year 2016, 187.
} 
rehabilitation institutions appointed by the government. On the other hand, for the prisoners who are in the category of both narcotics addicts and distributors, medical rehabilitation and or social rehabilitation can be carried out in prisons or detention centers. ${ }^{5}$

Law No. 35 of 2009, concerning Narcotics, authorizes judges to decide or stipulate a narcotics addict to undergo treatment through rehabilitation, as stipulated in article 103 paragraph (1) letters (a) and (b). Also, article 127 paragraph (2) states that "In deciding the case as referred to in paragraph (1), the judge must adhere to the provisions as referred to in article 54, 55 and 103. Furthermore, paragraph (3) mentions "In the case of abuse referred to in paragraph (1), if it can be proven to be a victim of narcotics abuse, the offender is required to undergo medical and social rehabilitation".

Nevertheless, the empirical data shows that in Banda Aceh and Jantho District Court, a verdict, deciding the person concerned to undergo treatment and or medical and social rehabilitation to cure his/her addiction to narcotics, is rarely found. The absence of a judge's decision concerning this matter has resulted in the rapid growth of narcotics crime. Even the order for medical and social rehabilitation is not established for the recidivists on narcotics cases proved guilty as users, as indicated in the provisions of article 127 paragraph (1), paragraph (2), and paragraph (3) also not decided or determined to undergo.

Following up this issues, the National Narcotics Agency (BNN) took the initiative by collaborating with Correctional Institutions (Lapas), as a place for guiding and preparing the convicts to be ready to return to the community, to carry out rehabilitation programs. However, in reality, as in Aceh Besar Regency and Banda Aceh, the cases of narcotics abuse have increased, the high rate of narcotics crime in the two regions can be seen in Table $1 .^{6}$

\footnotetext{
Pasal 7 ayat (1) dan ayat (2) Keputusan Bersama Ketua Mahkamah Agung Republik Indonesia Nomor: 01/PB/MA/III/2014, Menteri Hukum dan Hak Asasi Manusia Republik Indonesia Nomor: 03 Tahun 2014, Menteri Kesehatan Republik Indonesia Nomor: 11 Tahun 2014, Menteri Sosial Republik Indonesia Nomor: 03 Tahun 2014, Jaksa Agung Republik Indonesia PER005/A/JA/03/2014, Kepala Kepolisisn Negara Republik Indonesia Nomor: 1 Tahun 2014, dan Kepala Badan Nerkotika Nasional Republik Indonesia Nomor: PERBER/01/III/2014 BNN, Tentang Penangangan Pecandu Narkotika dan Korban Penyalahgunaan Narkotika Ke Dalam Lembaga Rehabilitasi

${ }^{6}$ Sumber Dari Buku Profil Kejaksaan Tinggi (Kejati) Aceh Tahun 2015 sampai dengan 2017.
} 
Table1

Recapitulation of Narcotics Cases in 2015-2017

\begin{tabular}{|c|c|c|c|c|l|}
\hline \multirow{2}{*}{ No } & \multirow{2}{*}{ Jurisdiction } & \multicolumn{3}{|c|}{ Year } & \multicolumn{2}{|c|}{ Remarks } \\
\cline { 2 - 6 } 1 & 2015 & 2016 & 2017 & \multicolumn{2}{|c|}{} \\
\hline Banda Aceh & 173 & 134 & 206 & $\begin{array}{l}\text { There is one decision that } \\
\text { decides the defendant requires } \\
\text { to be rehabilitated and } \\
\text { imprisoned. }\end{array}$ \\
\hline 2 & $\begin{array}{c}\text { Aceh Besar } \\
\text { Regency }\end{array}$ & 145 & 162 & 203 & $\begin{array}{l}\text { There are no decisions to } \\
\text { rehabilitate the defendant }\end{array}$ \\
\hline
\end{tabular}

Source: Adapted from the Aceh High Prosecutor's Office (Kejati) Book 2015 to 2017.

Table 1 shows that only one verdict ordered the addicts to join a rehabilitation center for drug abuse victims. This study aims to describe the rationales of the judges who did not order to rehabilitate and enforce rehabilitation for narcotics abuse addicts in Banda Aceh District Court and Jantho District Court of Aceh Besar. Data were obtained through in-depth interviews with detention officers, judges at Banda Aceh and Aceh Besar District Courts and the Public Prosecutors in Banda Aceh and Aceh Besar. The legal materials used consist of primary legal materials, secondary legal materials, and tertiary legal materials through the study of literature.

\section{Basic Considerations of Judges Not Deciding Narcotics Abuse Rehabilitation}

The sentences for offenders of crimes or violations depend on the judge in the Court. The judge will rule whether an act is right or wrong and determine the severity of the sentence, including deciding the sentence for drug addicts or offenders. The judge will decide based on the facts revealed in the trial after examining the witnesses and the evidence provided to trap the perpetrator.

The court authorized to prosecute narcotics crimes in the jurisdiction of Banda Aceh is Banda Aceh district court, while the criminal acts committed in the jurisdiction of Aceh Besar are handled by the Jantho District Court. Before submitted to the Court, a 
narcotics crime must follow a process, including the investigation at the police level, the prosecution at the prosecutor level, and finally the trial.

In deciding cases, judges in each court are bound to the evidence submitted by the public prosecutor or by the defendant's attorney to the trial. In Article 184 Paragraph (1), concerning the Criminal Procedure Code, states several pieces of evidence that can be used to trap the offenders of the crimes, namely: a) witness testimony, b) expert information, c) letter, d) instructions, and e) description of the defendant.

The evidence previously mentioned is important for the judge in deciding on a criminal case. The judge's conviction is one of the bases to trap the perpetrators at the trial. Because the evidentiary system adopted by the Criminal Procedure Code (Kitab Undang-Undang Hukum Acara Pidana -KUHAP) in Indonesia is a system of negative or negative evidence(negatief wettelijk stelsel), that is a minimum of two pieces of evidence and the judge's conviction. ${ }^{7}$ Therefore, lawyers and public prosecutors must submit evidence so that the judge is certain of all the evidence presented.

In narcotics crimes, proving whether the defendant is guilty or not is highly determined by the evidence prepared. Vice versa, the evidence is also required to prove whether the perpetrator has been consuming the narcotics for a long time or not. This evidence is vital considering that if the drug abusers have been on drugs for a long time, they are addicted. Thus, the judge decides whether the defendant should be rehabilitated or not. To explain that the defendant has been in the category of addicts, the presence of experts who know and understand the attitudes and behavior of narcotics addicts is paramount. The expert's information will be used as a basis for the judge in deciding the narcotics crime committed by the defendant. However, at the trial, the presence of experts receives less attention. As a result, the judge sentences the convicted narcotics offenders with imprisonment instead of rehabilitation.

In general, there are three underlying factors of the judge in deciding the sentence of imprisonment or rehabilitation for the defendant, that is:

1. Experts Not Presented to the Trial

7 Monang Siahaan, Falsafah dan Filosofi Hukum Acara Pidana, (Jakarta: PT. Grasindo, 2017), 37-38. 
Information from experts is an illustration of the importance of experts in providing information about a crime based on their expertise in their field. ${ }^{8}$ According to Article 1 number 28 of the Criminal Procedure Code, expert information is the information provided by a person who has special expertise about the matter to clarify in a criminal case for an examination. Article 186 of the Criminal Procedure Code determines that the expert's statement is what an expert declares in a court session.

Syaiful Bakhri argued that the existence of experts in the criminal court process is due to the limitations of the investigators and public prosecutors in revealing a criminal case at various stages. ${ }^{9}$ An expert who presents information does not necessarily have to witness or experience the events or a criminal act directly like an ordinary witness. Expert information about the cause and effect of a particular criminal act can be from the available evidence. Then, the expert concludes his opinion to assist in clarifying a criminal case. ${ }^{10}$

An expert can provide information to court orally or in writing. ${ }^{11}$ Expert testimony in the form of writing is usually presented in the an examination report. This provision is regulated in Article 187 letter c of the Criminal Procedure Code, which stipulates that a certificate of an expert containing an opinion based on his expertise regarding a matter or an issue officially requested from him ${ }^{12}$

Eti Astuti, one of the judges at Banda Aceh District Court who also served in Jantho District Court, mentioned that the existence of an expert who understands whether a narcotics abuse offender is an addict is very important. Experts, with their knowledge, can conclude based on medical examination and behavior observation of the drug abuse offenders so that they can inform the judge about the problems faced by the offender. ${ }^{13}$ By observing the attitude of the offenders, these experts can advise the judge to rehabilitate or imprison them. However, in practice at the court, the public prosecutor

Syaiful Bakhri, Sistem Peradilan Pidana dalam Perspektif Pembaharuan, Teori dan Praktik Peradilan, (Yogyakarta: Pustaka Pelajar, 2015), 123.

Syaiful Bakhri, Sistem Peradilan Pidana dalam Perspektif Pembaharuan, Teori dan Praktik Peradilan, (Yogyakarta: Pustaka Pelajar, 2015), 123-124.

Ibid.

Andi Sofyan, Abd. Asis, Hukum Acara Pidana Suatu Pengantar, cet. 2, (Jakarta: Prenada Media Group, 2014), 246.

Andi Sofyan, Abd. Asis, Hukum Acara Pidana Suatu Pengantar, cet. 2, (Jakarta: Prenada Media Group, 2014), 246.

Eti Astuti, Interview, A Judge of Banda Aceh District Court and has served as Jantho District Court Judge, May 30, 2018. 
or its legal counsel put limited attention to expert opinion. Both the prosecutor and the legal advisor never presented experts to the trial, neither the medical expert not the experts from the National Narcotics Agency. The expert's absence from the trial was one of the factors influencing the judge in deciding the imprisonment sentence for the defendant because no expert opinion presented to the judge. Therefore, the judge concluded not to sentence rehabilitation for the offenders to recover from drug addiction.

If the defendant submits an expert to the trial, the judge may consider providing rehabilitation. Even Eti Astuti, a judge, once sentenced the offenders with rehabilitation. In 2016, she decided on the rehabilitation of the defendant, who proved to be a narcotics abuse offender, M. Daud Bin Abdullah, case No. 103/ Pid.Sus/ 2016/ PN Bna.

In the case, it was decided for rehabilitation because the legal counsel presented the National Narcotics Agency (BNN) during the trial to explain that the defendant was undergoing a rehabilitation program to cure his dependence on marijuana-type narcotics before being arrested in the narcotics case. Based on these considerations, the panel of judges decided the dictum of the decision as follows.

1. One year imprisonment;

2. The defendant must undergo the treatment through medical and social rehabilitation in the Narcotics Victim Rehabilitation Institution of Aceh Province for five months, calculated during the period of the sentence established.

These empirical facts show that expert testimony has a strategic role in the trial and is influential for the defendant to be sentenced with rehabilitation or imprisonment. The drug abuse offender who presents experts, both from doctors and the National Narcotics Agency (BNN) is likely to sentence with rehabilitation. On the other hand, for those who do not present the experts will be likely to have imprisonment sentence.

\section{Perpetrators Do Not Admit As Drug Addicts}

The second common problem at the empirical level is that the defendant denies being a drug addict. The defendant admits that he or she has just used narcotics recently. This is a problem because the rules only provide rehabilitation for the offender who has been an addict or drug users continuously. If the defendant is categorized as the user or drug abuse offender, hs/he will be sentenced with imprisonment, as stipulated in Law No. 35 of 2009, concerning Narcotics. 
According to Rahmawati, almost all the defendants (charged with article 127 paragraph (1) of Law No. 35 of 2009, concerning narcotics) were those accused of being users who denied being narcotics addicts. All the defendants admitted that they only used narcotics once. ${ }^{14}$ This basis is used as a consideration by the judge in deciding on a criminal act of using narcotics with imprisonment sentence. Imprisonment or rehabilitation sentence is also highly determined by the testimony of the defendant and other evidence presented to the trial.

Judges through their beliefs can detect the defendants who have used narcotics several times by observing their attitudes and behavior when questioned at the trial. In the Criminal Procedure Code (KUHAP), the defendant's information is one of the evidence that can be used by the judge in deciding the case. Monang Siahaan stated that the defendant's statement is anything mentioned by the defendant in the court session related to the actions he has committed or which he knows or has experienced. ${ }^{15}$ The information conveyed by the defendant also influences the judge's decision. The severity of the decision, imprisonment or rehabilitation sentence, highly depends on the testimony of the defendant in addition to other evidence considerations.

Several reasons affects the defendant to deny himself or herself as an addict 16: First, the defendant concerns that if $\mathrm{s} / \mathrm{he}$ admits an a addict, s/he will be punished with a more severe sentence. Second, the defendant has lack of knowledge regarding the rehabilitation stipulated in the laws and regulations. The defendant thinks if $s /$ he has been arrested and detained due to narcotics abuse, s/he will be punished with imprisonment sentence. They are not aware of rehabilitation option.

\section{Never been sued by the public prosecutor}

One of the duties and responsibilities of the prosecutor is to file a criminal case to the court covering its jurisdiction after the documents are declared complete by the investigator . In addition, the duty of the prosecutor is to make an indictment to indict criminal offenders who are strongly suspected of committing criminal acts, prosecute and conduct the court decisions that have permanent legal force. In article 30 Paragraph

14 Rahmawati, judge of Banda Aceh District Court / Former Judge of the Jantho District Court, interview, 12 April 2018.

15 Monang Siahaan, Falsafah dan Filosofi Hukum Acara Pidana, (Jakarta: PT. Grasindo, 2017), 37.

16 Faisal Mahdi, Banda Aceh District Court Judge / Former Jantho District Court Judge, interview, June $25,2018$. 
(1) Law No. 16 of 2004, concerning the Prosecutor's Office, the duties and authority of the prosecutor in the field of criminal acts are as follows.

a. Prosecuting

b. Carry out the judge and court decisions that have permanent legal force;

c. Supervising the implementation of conditional criminal decisions, supervised criminal decisions and conditional release decisions;

d. Investigating certain criminal acts under the law;

e. Completing the documents for certain case and for that can conduct additional examination before delegating it to a court which is coordinated with the investigator.

The demands of the public prosecutor are one of the bases for judges in imposing rehabilitation or imprisonment on narcotics abuse offenders. However, most prosecutors did not ask the judge for the defendant to be rehabilitated so that the judge finally decided imprisonment sentence for the defendant. According to Eliyurita, the public prosecutor have never requested or prosecuted the defendant, who was proven to be a narcotics abuse offenders, to undergo rehabilitation to cure the narcotics dependence. ${ }^{17}$ Sadri, a judge at Banda Aceh District Court who had also served in Jantho District Court, also conveyed the similar issue and he argued that the public prosecutor should ask the judge for rehabilitation sentence for drug users. ${ }^{18}$

Despite the possibility of rehabilitation as stipulated in the law and regulations, without law enforcement efforts, it will be useless. The law has been comprehensive but when the law enforcers do not demand based the existing provisions, it will certainly lead to ineffectiveness in its application. Therefore, law enforcement officials need to utilize all regulations that have been formulated by the House of Representatives so that the laws can be useful for the community. interview, 20 May 2018. 
Satjipto Rahardjo argued that the law has no function if it is not implemented or enforced to the offenders, and law enforcers should enforce the law in the field. ${ }^{19}$ The law will not be useful, if it is only written but difficult to implement in community life, in regulating community behavior for a more orderly, peaceful and safe environment.

Due to the absence of rehabilitation demand, the judge's reference is imprisonment sentence. Even though the imprisonment costs are very high, it may not necessarily improve the offenders. Hazairin in his book entitled "Countries Without Prisons" once explained that no matter how good the imprisonment regulations are, no one thinks a prisons is equal to real moral education institutions. A community without prison is a high-quality philosophy and has enormous benefits ${ }^{20}$. Hazairin firmly stated that the elimination of the prison has a powerful economic benefit. It will save the costs for prison guard personnel, equipment, meals and medical treatment.

Similarly, Graham M. Sykes said that imprisonment sentence for criminals bring some negative impacts, namely: "The paint of Punishment: a. The deprivation of liberty; $b$. The deprivation of good and service; c. The deprivation of heterosexual relationship; d. The deprivation of autonomy; and e. The deprivation of security.,"21.

As imprisonment sentence brings many negative impacts, rehabilitation becomes a very suitable alternative to improve narcotics addicts. This will also determine their future.

\section{Implementation of Narcotics Abuse Rehabilitation in Banda Aceh and Aceh Besar}

The last place in the criminal law enforcement system is the correctional institution. Edi Setiadi believed that this institution has an important role in the criminal justice system because its existence determines the objectives established by the criminal justice system, especially the process of fostering the inmates so that they can be accepted by the wider community after serving their sentence. ${ }^{22}$

Correctional institutions play a role to enforce the court decisions of imprisonment and correctional services, ensure the protection of prisoners' rights, attempt to improve Kristian, Sistem Peradilan Pidana Terpadu dan Sistem Penegakan Hukum di Indonesia, (Jakarta: Kencana Prenada Media Group, 2017), 139.

21 Graham M. Sykes, The Paint of Punisment: Correction Problem and prospect. 53-56. in Koesno Adi, Diversi Tindak Pidana Narkotika Anak, Setara Press, 2014), 142.

22 Edi Setiadi, Kristian, Sistem Peradilan Pidana Terpadu dan Sistem Penegakan Hukum di Indonesia, (Jakarta: Kencana Prenada Media Group, 2017), 116-117. 
prisoners, and prepare prisoners to be able to return to society. In the context of recovery and rehabilitation, the role of correctional institutions is very important. The institution educates the prisoners the dangers of narcotics consumption.

The rehabilitation program has been implemented by the Class-IIb Detention Center in Banda Aceh, but it has not been optimum in providing rehabilitation for narcotics addicts. According to Tiara Amelia, Class-IIb Detention Center in Banda Aceh have carried out rehabilitation programs in 2016 and 2017. However, in 2018, it was implemented and it had become one of the issues. This rehabilitation program was conducted in collaboration between YAKITA Aceh and the Class IIb Detention Center in Banda Aceh, and all expenses was covered by YAKITA as the Detention Center did not allocate the budget for rehabilitation programs. ${ }^{23}$

The Class-IIa Detention Center of Banda Aceh only implemented the rehabilitation program in 2015 and 2016, while such program was no longer available in 2017 to $2018 .^{24}$ According to Ruslandani, the rehabilitation program was carried out by the Class-IIa Correctional Institution of Banda Aceh in Lambaro in collaboration with Aceh Provincial Office of National Narcotics Agency (BNN), which also involved YAKITA Aceh. The costs were fully borne by the BNN because it is one of the programs of the BNN headquarter, while the Ministry of Law and Human Rights or Correctional Institutions provided neither such program nor the budget allocation.$^{25}$

This lack of budget is the main factor influencing the failure of the rehabilitation program. The program will be only conducted if there is a collaboration with the National Narcotics Agency (BNN) or other parties (foundations) engaged in narcotics rehabilitation. Its sustainability cannot be maintained because the Ministry of Law and Human Rights, and the National Narcotics Agency (BNN) do not provide a budget for the program. As a result, the rehabilitation process, both medical and social rehabilitation, cannot be run for narcotics addicts.

The rehabilitation activities was carried out in the hall, clinic, and prayer room in the detention center. However, the rehabilitation program done by the class-IIb detention center in Banda Aceh is only social rehabilitation, unlike Class-IIa detention center in

23 Tiara amelia, Staff of the Class-IIb Detention Center of Banda Aceh, interview, July 25, 2018

24 Meiky Mendra, Head of Guidance for Prisoners at the Class IIa Correactional Institution in Banda Aceh, interview, July 29, 2018

25 Ruslandani, Staff of the class-IIb Detention Center of Banda Aceh, interview, July 29, 2018. 
Banda Aceh which also carried out medical and social rehabilitation. Meiky Mendra mentioned that the rehabilitation program implemented is medical and social rehabilitation, to cure the inmates' dependence on narcotics and to prepare narcotics prisoners who will return to society after serving their imprisonment terms. ${ }^{26}$

They provided social rehabilitation by promoting the understandings concerning the drug effects to narcotics inmates who will return to the community after serving the imprisonment sentence. The education was run by YAKITA Aceh. In addition, the counselor from YAKITA Aceh also motivated the prisoners to be mentally prepared to return to the community and run a discussion session involving former addicts who were assisted by Yakita Aceh. ${ }^{27}$

The Correctional Institution aims to change the traits, ways of thinking and behavior of the inmates as well as conduct educational interaction processes. In other words, the type and process of interaction developed both by fellow inmates, officers, and other staff must be educational to fulfill the principles of honesty, justice, and humanity. Intensive interactive education is necessary so that the awareness of the prisoners concerning the right behavior develops. ${ }^{28}$

BNN also supervised the rehabilitation program for 24 days by placing BNN officers in Lambaro detention center (three months/batch). ${ }^{29}$ The supervision aims to enable participants to gain a comprehensive understanding of the effects of narcotics and prepare them return to the community. This is also the ideal role played by the Correctional Institution, that is educating prisoners who have violated the laws and norms of the community. ${ }^{30}$

The rehabilitation program in Class IIb Detention Center in Banda Aceh was carried out once a week (approximately 3 hours) for three months. The rehabilitation activities were run in the prayer room at the detention center involving 25 participants, as

Meiky Mendra, Head of Guidance for Prisoners at the Class IIa Correactional Institution in Banda Aceh, interview, July 29, 2018.

Yusaini, Head of Sub-Department of Prisoners in Class IIb Detention Center of Banda Aceh, interview, July $25,2018$.

David J Cooke, Pamela J Baldwin \& Jaqueline Howison, Menyingkap Dunia Gelap Penjara, terj. Hary Tungga [Revealing the Dark World of Prison]. (Jakarta: Gramedia Pustaka Utama, 2008), xiv.

Ruslandani, Staff of the class-IIb Detention Center of Banda Aceh, interview, July 29, 2018.

David J Cooke, Pamela J Baldwin \& Jaqueline Howison, Menyingkap Dunia Gelap Penjara, [Revealing the Dark World of Prison], (Jakarta: Gramedia Pustaka Utama, 2008), Xiii. 
requested by YAKITA Aceh. The participants were chosen based on the following criteria: ${ }^{31}$ :

1. Participants are the convicted by article 127 paragraph (1) of Law No. 35 of 2009 (proven as a narcotics abuse offender)

2. The assessment of officers reveals that the convicted are eligible for the rehabilitation program.

3. There is a request from the family of the convicted related to narcotics cases or a narcotics addict.

The rehabilitation program in Class IIa Correctional Institution in Banda Aceh was also conducted by the National Narcotics Agency (BNN) for three months, involving 30 participants selected from several detention centers and correctional institution in Aceh. The criteria of the participants set by the BNN is that they must be narcotics related convicts whose imprisonment is almost due. Both medical and social rehabilitation activities took place in the Class IIa Correctional Institution in Banda Aceh and also involved Yakita Aceh as a counselor for the social rehabilitation program, while medical rehabilitation was directly handled by a team of doctors from the National Narcotics Agency (BNN). ${ }^{32}$

There are challenges faced by the officers in implementing rehabilitation in both the correctional institutions and detention centers. One of them is that the selected participated reunited with other prisoners. Consequently, they are vulnerable to be affected and exposed to narcotics cases. The separation cannot be done due to the limited space to accommodate prisoners of various cases. ${ }^{33}$ Separation is highly recommended in the future so as not to prisoners who have been rehabilitated and other prisoners will not be mixed.

\section{Conclusion}

Based on the discussion presented previous sections, it can be concluded that the judge does not order rehabilitation for narcotics addicts because the public prosecutor and

31 Yusaini, Head of Sub-Department of Prisoners in Class Ilb Detention Center of Banda Aceh, interview, July 25, 2018.

32 Ruslandani, Staff of the class-IIb Detention Center of Banda Aceh, interview, July 29, 2018.

33 Tiara Amelia, Staff of the class-IIb Detention Center of Banda Aceh, interview, July 29, 2018. 
advocate have never presented an expert to the court. Thus, it is difficult for the judge to conclude that the defendant is a narcotics addict. In fact, the presentation of experts to the trials based on their expertise can provide information that the defendant are truly addicted and requires both medical and social rehabilitation. Subsequently, the other problem is that the defendant rarely admit that they are narcotics addicts, instead they say that they have only consumed narcotics recently. Consequently, the judge sentences him imprisonment so that he can be guided in a correctional institution. The last issue is that the public prosecutor has never demanded for the offender to be sentenced with medical or social rehabilitation. On the contrary, the public prosecutor demands for the defendant to be imprisoned.

The rehabilitation program for narcotics abuse offenders highly depends on the budget provided by the government through the National Narcotics Agency (BNN). Rehabilitation is conducted in two forms, namely social and medical rehabilitation by providing education and knowledge about the consequences of narcotics abuse. It also fosters the awareness of not repeating narcotics abuse, prepare them to return to the community, and heal the narcotics addition medically.

\section{Bibliography}

Aswin Pramudita, "Pertimbangan Hukum Hakim Menjatuhkan Sanksi Pidana Penjara Terhadap Penyalahgunaan Narkotika Tanpa Menerapkan Rehabilitasi Medis (Studi Putusan Nomor: 100/PID.SUS/2015/PN.SKT)", Jurnal Verstek, Volume 5 No. 2 MeiAugust 2017.

Andi Sofyan, Abd, Asis, Hukum Acara Pidana Suatu Pengantar, cet. 2, (Jakarta: Prenada Media Group, 2014).

David J Cooke, Pamela J Baldwin \& Jaqueline Howison, Menyingkap Dunia Gelap Penjara, terj. Hary Tunggal. (Jakarta: Gramedia Pustaka Utama, 2008).

Edi Setiadi, Kristian, Sistem Peradilan Pidana Terpadu dan Sistem Penegakan Hukum di Indonesia, (Jakarta: Kencana Prenada Media Group, 2017). 
Graham M. Sykes, The Paint of Punisment: Correction Problem and prospect. in Koesno Adi, Diversi Tindak Pidana Narkotika Anak, Setara Press, 2014.

Hafrida, Kebijakan Hukum Pidana Terhadap Pengguna Narkotika Sebagai Korban bukan Pelaku Tindak Pidana: Studi Lapangan Daerah Jambi, Jurnal Ilmu Hukum, Universitas Padjajaran, vol. 3, Number 1, year 2016

Hazairin, Tujuh Serangkai tentang Hukum, $4^{\text {th }}$ Printed ver, (Jakarta: Bina Aksara, 1985).

Monang Siahaan, Falsafah dan Filosofi Hukum Acara Pidana, (Jakarta: PT. Grasindo, 2017).

Satjipto Rahardjo, Ilmu Hukum, (Bandung: Pt. Citra Aditya Bakti, 1991), page. 153. in Edi Setiadi, Kristian, Sistem Peradilan Pidana Terpadu dan Sistem Penegakan Hukum di Indonesia, (Jakarta: Kencana Prenada Media Group, 2017).

Syaiful Bakhri, Sistem Peradilan Pidana dalam Perspektif Pembaharuan, Teori dan Praktik Peradilan, (Yogyakarta: Pustaka Pelajar, 2015).

Undang-undang Nomor 35 tahun 2009 tentang Narkotika.

Keputusan Bersama Ketua Mahkamah Agung Republik Indonesia Nomor: 01/PB/MA/III/2014, Menteri Hukum dan Hak Asasi Manusia Republik Indonesia Nomor: 03 Tahun 2014, Menteri Kesehatan Republik Indonesia Nomor: 11 Tahun 2014, Menteri Sosial Republik Indonesia Nomor: 03 Tahun 2014, Jaksa Agung Republik Indonesia PER-005/A/JA/03/2014, Kepala Kepolisisn Negara Republik Indonesia Nomor: 1 Tahun 2014, dan Kepala Badan Nerkotika Nasional Republik Indonesia Nomor: PERBER/01/III/2014 BNN, Tentang Penangangan Pecandu Narkotika dan Korban Penyalahgunaan Narkotika Ke Dalam Lembaga Rehabilitasi. 